\title{
THE EFFECTIVENESS OF ROUND ROBIN SUMMARIZING ON READING COMPREHENSION FOR THE TENTH GRADES STUDENTS OF SMA NAHDLATUL ULAMA 2 GRESIK
}

\author{
Khilayatus Sholihah \\ SMA Nahdlatul Ulama 2 Gresik \\ E-mail: khilayatus.sholihah@gmail.com
}

Received: July 10, 2017

Accepted: August 17, 2017

Published: August 31, 2017

dei:10.7575/aiac.ijels.v.1n.1p.1_ URL: http://dx.doi.org/10.7575/aiac.ijels.v.1n.1p.1

\begin{abstract}
Reading has an important role towards speaking in which speaking needs much vocabulary knowledge to develop ideas in communication. By reading activity readers can obtain much information. English as foreign language has some aspects in learning it. So, the aspect can be mastered by appropriate strategy. One of the strategies is round robin summarizing technique. Round robin summarizing can be one of strategy in learning reading skill. The purpose of this research is to investigate the significant effect of round robin summarizing in reading skill for 10th grade students at SMA Nahdlatul Ulama 2 Gresik in academic year of 2016/2017. In this research, the researcher used quantitative research and it refers to experimental research design because the purpose of the research is to investigate the effect of round robin summarizing on students' reading comprehension. This research started during December, 2016. The population of this research was the tenth grade students of SMA Nahdlatul Ulama 2 Gresik. Because the population is large the researcher decided to use cluster sampling technique to select two classes with the same ability. Two classes were taken as the sample of the research. Those are X-A as the experimental group and X-B as the control group. The data tested using t-test formula by comparing the mean score of pre-test and post-test from both of classes. The result of post-test score mean showed that experimental group was higher than control group. The post-test score mean of the experimental group was 58.67 while the control group was 53.12. The result of this study showed that probability value both of the groups was $0.000(0.000<0.005)$. This result showed that the experimental group and the control group were different in their ability after giving treatment. So, the null hypothesis could be rejected. Then, the null hypothesis stated that there was significant different using round robin summarizing towards students' reading comprehension between experiment and control groups. Based on the description above, the researcher found that there was significant different in reading comprehending between the students who were taught using round robin summarizing and who were taught without using round robin summarizing. Having known from the finding of the study, it was indicated that round robin summarizing significantly influence towards students' reading comprehension of students at SMA Nahdlatul Ulama 2 Gresik. For further researcher, the researcher hopefully round robin summarizing can be used in different skill.
\end{abstract}

Key words: Round Robin Summarizing, Reading Comprehension.

\section{Introduction}

Language is used as tool to communicate with other people. Larsen (2000:2) states that language is a bridge to connect one another. People realize that language has an important role in society to express their ideas. Thus, with language human can gain information and knowledge either orally or written. In learning language, there are four skills should be mastered by students. Those skills are listening, speaking, reading and writing. Listening and reading refers to receptive skills while speaking and writing refers to productive skills (Scrivener,1994:20). Four language skills are integrated and support each other to make language learning success. Reading has an important role towards speaking skill in which speaking needs much vocabulary knowledge to develop ideas in communication. By reading activity readers can obtain much information. It is supported by Carrell and Eisterhold (1983) state that reading activity can increase the knowledge of readers. Therefore, reading is benefit for someone life not only addition knowledge but also develop ideas in communication.

Teaching reading by using round robin summarizing can help students to conduct students' progress in reading comprehension. Students are able to conclude the main ideas and make the paragraph shorter than original text. The short explanation above shows that round robin summarizing had significant effect to use in teaching reading. Therefore, researcher hopes this strategy can help students in comprehending the whole content text based on their own 
understanding. Here, students' ability in comprehending text is different. It means that not all of students have same ability in comprehending text. By doing round robin summarizing activity students can solve their problem in transferring meaning text through cooperative among one another. According to Kagan (2009) round robin is useful to develop the critical thinking through cooperation within the group (Teambuilding), not only develop the critical thinking student in solve the problem of reading comprehend but also learn how to cooperate with their teammates and the whole class can participate in the lesson actively.

Many researchers found that summarizing technique connected with reading and writing. Corbeil (2000) pointed out that summarization becomes assessment to conduct students' progress in reading comprehension skill meanwhile reading has effect towards students' writing skill (LIU, 2008). In which, this strategy helps students to conclude main ideas the whole paragraph through paraphrasing process. As stated by (Brown, Day\& Jones, 1983) that through summarization students learn how to reread and activate prior knowledge. It can be said that if students can summarize well, exactly they improve their reading ability (Budi, 2009; Palmer, 2003). It is valuable practice for students in developing reading and writing skills, also it is related to paraphrasing (Sotitiou, 2002). Besides, using a summarizing technique is better to avoid students on plagiarism and distortion.

Summarizing technique is kind of reading strategy to avoid copy sentences from the original text. With summarizing technique students are able to develop their critical thinking. The result of the research shows that summarization had significant effect on reading comprehension (Baumann, 1984; Bean \& Steenwyk, 1984; Taylor \& Beach, 1984). In which, students is able to refine the main ideas whole paragraph and make simple sentence based on their own words. It is supported by Brown, Day and Jones cited in Moghaddam (2007) declared that summarization means make simple sentence to easier understanding. Further, researcher wants to try to test the theory about round robin summarizing as well as alternative methods of learning reading. The researcher choice of the tenth grade students is based on some reasons. First, the tenth grade students were taken as the best choice to conduct the research because the topic of narrative and procedure included in the tenth grades. Second, it was also impossible for the researcher to take research in the twelve grades because students were in the preparation for national examination. They had a particular schedule if the researcher involves them.

Referring to the background of the study previously presented, the researcher formulates the statement of the problem as follows:

1) Is there any significance effect of round robin summarizing toward students' reading comprehension for the tenth grades students of SMA Nahdlatul Ulama 2 Gresik?

\section{Literature Review}

The Definition of Reading

Reading is one of the four language skills which it is a receptive skill as same as listening Spratt, Pulverness, and Williams (2005:21). They are many experts defines what reading is. According to Mikulecky and Jeffries (1996:1), reading is one important why to enlarge students' vocabulary. In this regard, reading is really useful for students to receive any information. Reading is an activity to gain information or knowledge. In reading activity, the reader doesn't separate interaction between reader and writer (Goodman, 1990: 23). It means that when the readers read the text, they communicates with the writer's writing, they can understand what the writer means. Otherwise, when the writer wants to deliver their ideas to write, they will be read the text first. In principle, reading is a process to understand the written message available in the text. Lado (1964:131) describes that reading is as an activity to understand whole sentences based on their written representation. In addition Johnson (2008:3-4) defines that reading is an activity link a printed word to create meaning about the text. Learning language without reading is meaningless. Reading skill is one key to understand all references, books, and newspaper. More reading means more knowledge. Ramelan (1990:2) stated reading will be useful for the students. By reading magazines, newspapers, and some kinds of subject books will increase in maturity. It can be concluded that reading as important to learn for students either at school or after they graduate from their study.

Harmer (1998:68) states that reading has many functions especially for student and they are:

a. Reading provides good models for English writing. By reading, the writer is able to write because when they read the references it means that they can explore their ideas in writing.

b. Reading provides opportunity to study language such as vocabulary, grammar, and punctuation. By reading activity, the readers will comprehend those aspects well.

Therefore, it is useful to explore our ideas and get knowledge about variation vocabulary and grammar that is concluded in the text.

Brown (2001:312-313) there are two types of reading those are intensive reading and extensive reading

\section{Intensive Reading}


Intensive reading is usually a classroom-oriented activity in which students focus on the linguistic or semantic details of a passage. The intensive reading has the specific purpose like knowing the grammatical forms, discourse markers, and other surface structure details for the purpose of understanding literal meaning, rhetorical relationship.

\section{Extensive Reading}

Extensive reading is carried out to achieve a general understanding of a usually somewhat longer text (book, long article, or essays, etc). Extensive reading is also to obtain a general understanding of a subject and include reading longer text for pleasure. Usually extensive reading is done in the outside of class time for example reading for purpose. It is reading activity that in teacher encourages students to choose for themselves what they like to read and to do so for pleasure and general language improvement.

Harmer (2001:70) explained that there are some principles of teaching reading

a. Reading includes active skill

Reading is an active skill where students have to understand what the word means.

b. Teacher encourage the students

It means that the students have to respond to the content of the text, not only for the language but also

c. Prediction becomes a major factor in reading

Book cover gives them a hit of what is in the book that is read by the students before they read the text in their own language.

d. Teacher matches the task to the topic

The teacher gives the most interesting text through exciting imaginative and challenge task.

e. Good teacher exploit the reading text to the full

Many reading texts are full of sentences, words, ideas and description. It does not make teaching and learning reading process is less interested. Good teacher integrates the reading text is using the topic for discussion and further task, using language for study and activation.

Teaching Reading in Senior High School according to KTSP

According to KTSP, teaching reading in senior high school aims to develop the students' ability to comprehend and create kinds of short functional text and monologue and essay formed recount, narrative and procedure. The students also hope that they can read the texts which have meaning of word, phrase and sentence with the utterance, stress and intonation related with the near area. The students responds the simple short functional of written text accurately and fluently.

The Definition of Comprehension

The essence of reading act is comprehension. Comprehension means understanding the meaning or the point of a topic, F. Dubin, D.E Eskey and W. Grabe (1986:6). Reading comprehension is very important when we read newspaper, magazine, and books. We need to understand the reading passage. Someone cannot get information completely without comprehension. Comprehension includes understanding main ideas and related details. Additionally, Penny Ur (1996:138) states that in reading, it is recorded the meaning of text and our understanding of which it is composed.

Leu and Kinzer (1987:30-31) stated that there are six major components of reading components

a. Decoding knowledge

Decoding knowledge is important to be comprehended when determining the oral equivalent of a word helps a reader identify meaning. Knowing how to determine the oral equivalent of a written word enables beginning readers to access the meaning of most words in the oral language.

b. Vocabulary knowledge

Vocabulary knowledge means word meaning used to determine the appropriate meaning of a word in particularly context. It is a particularly important aspect of reading instruction as children develop.

c. Discourse knowledge

Discourse knowledge means knowledge of language organization at units beyond the single sentence level includes the knowledge of structural organization in different types of writing. It is useful during reading comprehension. Besides that, it is used to know whether or not you're reading in likely to be true.

d. Readiness aspect

Reading readiness is the ability of the students to benefit from initial reading instruction. Reading instruction, in this case, consist of activities that prepare the students to read a specific story such developing background knowledge about the topic of the selection, learning new vocabulary word, understanding the purposes for reading selection.

e. Effective aspect

Reading is language process, but it is also an effective process, effective process of comprehension includes a reader's attitude and interesting reading. Interested in reading better to increase motivation and facilitate reading. 


\section{f. Syntactic knowledge}

Syntactic knowledge means knowledge of word to determine grammatical function and meaning the pronunciation of words. The more syntactical pattern is important to develop treading ability and as the structure of the sentence.

\section{Definition of Narrative Text}

Narrative is kind of text that tells imaginative and fictive story to entertain the reader. Narrative tells a story. It is the kind of writing found in novels, short stories, and biographies. Narrative usually follows time order. Narrative has generic structure.

\section{The Types of Reading Text}

The types of reading texts are learned by students in school. They are descriptive text, narrative text, spoof, recount text, Procedure text, Report text and anecdote. Students are expected to understand and master all of the texts after they learnt English.

\section{The Generic Structure of Narrative Text}

a. Orientation

It introduces the characters of the story, setting, when, where the story happened.

b. Complication

It is when the problem appears among the characters.

c. Resolution

It is when the problem can be solved.

d. Re-orientation

Optional

The Definition of Round Robin Summarizing

Kohonen (2003:36) points out that in a good group of cooperative learning, there are a heterogeneous group which consist of four members including a high achiever, one/two average achievers, and low achievers. These statements are supported by Jacobs (2006:31-32) which explains about the benefit of placing students in group of four. He states, larger groups (more than two) have advantages as well, because for more complex tasks, where are more people and perhaps cooperative learning has a wider range of skills and knowledge from which to draw.

Jacobs, Lee, \& Bell (1997:28) explain that this technique is called roundrobin, because they go round in a circle with each person getting a chance to talk justlike Robins sings. The groups use cooperative technique round robin todiscuss their own beliefs about learning. Moreover according to Kagan\& Kagan (2009), the implementation of round robin summarizing improves their social skill. They also explain that there is a spectrum of social skills required to be a good team member.

Round robin summarizing is one of cooperative learning strategies in which students take turns contributing answers in a group. This technique is designed to give everyone in the group an equal chance at participation. Based on Kagan (2009) said that learning procedure for round robin starting with forming groups, each group consists of 4 to 6 students. Students solve the problem with group discussion and written answer. Each person gets 1-3 minutes going clockwise or counterclockwise, to present their point of view. A question is posed with many answers and students are given time to think about answers. After the "think time," members of the team deliver their answer with one another in round robin style. Others groups as listeners and responders. This technique can be used as a warm up, evaluation, or to share something learned or a point of view. Once the groups have completed the task, each group shares its collective responses with the whole class.

\section{Methods}

The research design of this research uses quantitative research and it refers to experimental research design because the purpose of this research is to investigate the effect of round robin summarizing on students' reading comprehension. In this research, the researcher uses quasi-experimental research in which quasi-experimental are sometimes called natural experiment because in a school setting, it is impossible for researcher to assign subjects randomly to group in other word the researcher is forbidden to change class arrangement. Quasi-experimental design focuses on treatment and outcome.

\section{Population and Sample}

The population of the research was the tenth grade students of SMA Nahdlatul Ulama 2 Gresik in the first semester 2016 / 2017 academic year whose level of English proficiency was supposed to be some. The amount of population in the tenth grade students of SMA Nahdlatul Ulama 2 Gresik in the first semester 2016 / 2017 are 150 
students. Because the population is large in other word the researcher decided to use cluster sampling technique to select two classes with the same ability. One class as the experimental group and the other one as the control groups considered that both of the classes are regular class.

By using cluster sampling technique, $\mathrm{X}-\mathrm{A}$ and $\mathrm{X}-\mathrm{B}$ were chosen as the sample among those classes. X-A as the experimental group which consists of 30 students and X-B as the control group also consists of 30 students.

Data Collection

Instrument

There are two tests are used by researcher (Pre-test and Post-test) for control group and experimental group. The test is used to know whether there is significance difference on students' reading comprehension using round robin summarizing or not. Actually, the tests of pre-test and post-test are different but, the topic of the material is same. There are same in format, instruction, level of difficulty and allocated time. The researcher decided to use the multiple choice type in the reading test of pre-test and post-test. There are 20 items in every tests, it means that 20 items for pre-test and 20 items for post-test then, every correct answer could 5 points and incorrect answer could 0 points, totally 100 points. Time allocation for students to finish the reading test is 90 minutes.

Before giving the test the research measure the validity and reliability of test to know whether the test are propend to be given for students or not by doing try out. The researcher ensured the validity of the research by matching the test item with the curriculum. Then for ensuring the reliability of those test, the researcher conducted the try out to other class which is XD consists of 30 students.

Data Analysis

Analysis the data of test

The purpose of analyzing data is to answer the research problem with get through pre-test and post-test. The researcher uses independent sample Ttest because the sample is small and the groups are independent. The steps applied in analyzing pre-test and post-test were scoring, normal distribution test, homogeneity test, if the data is normally distributed and homogeneity, independent T-test was conducted to analyze the significance different between experimental group and control group.

Hypothesis Testing

Independent T-test is used to find out the significance between experimental group and control group. Here the steps of T-test calculation. The first is started the hypothesis and setting the alpha at the level 0.05 (two tailed test). In this research, the hypothesis used null hypothesis that said "there is significance difference on the use round robin summarizing on students' reading comprehension between experimental group and control group.

The hypothesis can be formulated as follow:

Null hypothesis is $\mu 1-\mu 2=0(\mu 1=\mu 2)$

Alternative hypothesis is $\mu 1-\mu 2 \neq 0(\mu 1 \neq \mathrm{u} 2)$

H1 =Students' reading comprehension through round robin summarizing

$\mathrm{H} 2$ =Students' reading comprehension through without round robin summarizing

Hypothesis testing in this research was:

$\mathrm{H} 0=$ There is no significant difference on appying round robin summarizing on students'reading comprehension between experiment and control groups

$\mathrm{H} 1$ = There is significant difference on applaying round robin summarizing on students' reading comprehension between experiment and control groups.

The second step was finding t-value using independent T-test formua and comparing the probability with the level of significance for testing the hypothesis. Determining t-critical in table $t(0.05) \mathrm{df}$, the researcher compared $\mathrm{t}$ observed and $\mathrm{t}$-critical. If $\mathrm{t}$-obs $<\mathrm{t}$-critical, the researcher should accept the null hypothesis and if $\mathrm{t}$-obs $>\mathrm{t}$-critical, it means the researcher can accept the alternative hypothesis.

T-test was calculated to find out the comparison of two means between experimental and control group pre and post test, in analyzing the data, the researcher used independent T-test formula. The formula is:

$$
t=\frac{\left(x_{1}-x_{2}\right)-\left(\mu_{1}-\mu_{2}\right)}{S x_{1}-x_{2}}
$$

Where:

$\mathrm{t}=$ Is $\mathrm{t}-\mathrm{value}$ 
$\mathrm{x} 1$ =Is average group 1

$\mathrm{x} 2$ =Is average group 2

$\mathrm{S}=$ Is standart error of two groups

$\mu 1-\mu 2=$ Is always defaults to $0 \mathrm{~s}$

$$
S x_{1}-x_{2}=\sqrt{\frac{S^{2} \text { pooled }}{n_{1}}}+\frac{S^{2} \text { pooled }}{n_{2}}
$$

Where:

Sx $1-x 2=$ Is standart error of two groups

S2pooled =Is variants of two groups

$\mathrm{n} 1=$ Is number of sample group 1

n2 =Is number of sample group 2

Pooled variance $=$ The average of two sample variances, allowing the larger sample to weight more heavily.

Formula:

Estimated standart error of the difference

$$
S x_{1-} x_{2}=\sqrt{\left(\frac{S S_{1}+S S_{2}}{n_{1}+n_{2}-2}\right)\left(\frac{1}{n_{1}}+\frac{1}{n_{2}}\right)}
$$

Therefore, the results of the test were subjected for the following statistical procedures. To calculate t-test, the researcher uses SPSS (Statistical product and service solution) version 16.0. The post test score experimental and control group were analyzed by using SPSS version 16.0 with the following procedures. The first procedure was inserting the post test data both experimental and control group using the data view. The second procedures were going to the analyze menu, selecting compare means, then choosing independent sample $t$ test output, automatically it could answer to the research question about the comparison between two groups. The final result was collected by means of pre test and post test score. It is aimed to find out the significance of the effect round robin summarizing on students' reading comprehension.

\section{Findings}

Homogeneity test was done to know the variant of the data students' reading comprehension in narrative text are same or not. For homogeneity test, the researcher uses Levine's test of homogeneity in SPSS 16.0 program.

To analyze the homogeneity, the researcher used SPSS version 16.0 program. The homogeneity assumption was checked in SPSS by Levene's test with the following procedures. The first procedure was Inserting the pre-test data both experimental and control group using the Data View. Click Analyze Menu, selecting Compare means, and choosing Independent Sample T-test. The last, interpreting the homogeneity test output, see Levene's test Column to know whether the quality of variance in the group of score were homogeneity or not.

Based on the table output SPSS above showed that $\mathrm{p}$ value was 0.844 it means that the level of significance $0844>0.05$. So, the scores of the experimental and control groups were homogeneity, no difference variance between experimental group and control group.

From the table above, the researcher found that sig. (2 tailed) of experimental group and control group was 0.002. It showed that the significance level less than alpha (0.05). It means that the null hypothesis can be rejected. So, the researcher can accept $\mathrm{H} 1$ and concluded that there was significance effect on the use of round robin summarizing on students' reading comprehension between experimental group and control group.

Furthermore, the results showed that there was significance different in reading comprehension between experimental group and control group. It can be seen the average score of experimental group higher than control group, where the average score of experimental group was 53.1667 but control group was 58.6667. It means that there was significance influence the use of round robin summarizing on students' reading comprehension between experimental group and control group.

\section{Discussion}


The result of data analysis which was established as the findings of the research showed that round robin summarizing given positive significance towards students' reading comprehension for the tenth grades students of SMA Nahdlatul Ulama 2 Gresik. The mean pre-test of experimental class was 52.83 while the mean post-test of experimental class was 58.67. Post test score of experimental class convincingly much higher than the mean of pre test score of experimental class. This result showed that this research appropriated the hypothesis testing.

It can be seen from the steps of students who were taught reading narrative text by using round robin summarizing in which, the students gather in around the table to solve the problem and share ideas, in this section students learned how to respect towards differences opinion and students had same opportunity to explain their ideas about their summarization by using rotation process for about 3 / 4 rotations. Students make summarize based on their own words without copy paste the language used in the text. Here, teacher can be checked the students' understanding towards the text that they read.

And the last steps, students share their summarization in group discussion. Round robin summarizing gave positive influence for students' comprehension towards reading narrative text in which students can be repaired their ability in comprehend text by using this technique. Here, students think about what they expect the passage to be read, by using this technique students can summarize the whole of passage and identify the message of text. Students learned to find the major details of the text more specific by share ideas of summary in discussion forum.

The explanation showed that teaching reading narrative text significantly after they had been taught through round robin summarizing. Round robin summarizing was allowing all students to contribute tin identify the content of text. Here, students can build their knowledge and create positive response when students had contribute in share ideas of their summary take turn from left to right. Reviewing material through summarizing technique was useful for students to avoid copy paste answer and it was also easier for teacher to check the comprehension students.

\section{Conclusion}

Teaching reading narrative text by using summarizing technique gave influence towards students' reading comprehension. In which students refine the main ideas whole paragraph and make simple sentence based on their own words without share in discussion forum. While teachings reading narrative text by using round robin summarizing gave positive significance towards students' reading comprehension. Which were students had same contribution to refine the main ideas whole paragraph and make simple sentence based on their own words by share ideas of summary in discussion forum

The researcher concluded that teaching reading narrative text for the tenth grades students of SMA Nahdlatul Ulama 2 Gresik was more effective by using round robin summarizing than teaching reading narrative text for the tenth grades students of SMA Nahdlatul Ulama 2 Gresik by using summarizing technique.

\section{Suggestion}

The researcher wants to give contribution following suggestion based on the conclusion above:

English teacher of Senior High School are suggested to use round robin summarizing as an alternative strategy in teaching reading. The researcher should be well prepared the materials of reading that are going to be taught to the students which it has been proven that students can learn easier to comprehend the material of reading text through share ideas of their summarization in discussion forum.

Students who learn in Senior High School are suggested to use round robin summarizing which it has been proven that students have more knowledge in comprehend text through share ideas of their summarization with their group discussion. The students should be well having more vocabulary knowledge that is going to be read the reading text.

Further researcher who have the same problem and interested in carrying out a research in similar field, hopefully this study can be implemented better than the first researcher conducted it. The researcher is suggestion to next researcher more creative in activity discussion.

\section{References}

Baumann.,Bean \& Steenwyk.,Taylor \& Beach. (1984). The effect of three forms of summarization on sixth graders' summary writing and comprehension. Journal of Reading Behavior, 16, 297-307.

Brown, A., Day, J., Jones, R. (1983). The development of plans for summarizing texts. Child Development, 54(4), 968-979.

Brown, H, Douglas. (2001). Teaching by Principles, an Interactive Approach to

Language Pedagogy. New York: Addison Wesley Longman.

Carrell, P. L. \& Eisterhold, J. C. (1983). Schema theory and ESL reading 
pedagogy. TESOL Quarterly, 17(4), 553-573.

Corbeil, G. (2000). Exploring the effects of first-and second-language proficiency on summarizing in French as a second language. Canadian Journal of Applied Linguistics, 3(1-2), 35-62.

Dubin, Eskey, D.E.F and Grabe, W. (1986). Teaching Second Language for Academic Purposes. New York: Addison Wesley.

Goodman, Kenneth. (1990). The Reading Process, In Patricia L. Carrel,(eds),Interactive Approach to Second Language Reading. Cambridge: Cambridge University Press.

Harmer, J. (1998). How to Teach English: An Introduction to the Practice of English Language Teaching. Essex, England: Pearson Education Limited.

Harmer, Jeremy. (2001). The Practice of English Language Teaching. Edinburgh Gate: Pearson Education Limited.

Jacobs, G. M. (2006). Issues in implementing cooperative learning. In Mccafferty et al (Ed.).Cooperative Learning and Second Language Teaching. USA :

Cambridge University Press.

Jacobs, Lee, and Bell. (1997). Learning Cooperative Learning Via Cooperative Learning. Singapore: SEAMEO Regional Languange Centre.

Kagan, S. (1992). Cooperative learning. San Clemente: Resources for Teachers Inc.

Kohonen, V. (2003). Experential Language Learning. In Nunan,D (Ed.), Collaborative Language Learning and Teaching. New York: Cambridge University Press.

Kagan, S\&Kagan, M. (2009). Kagan Cooperative Learning. San Clemente: Kagan Publishing.

Lado, R. (1964). Language Teaching A Scientific Approach. New York: Me Grawhill, inc.

Larsen, Diane and Freeman. (2000). Teaching and Principles in Language Teaching. New York: Oxford University Press.

LIU Xiao-juan. (2008). Exploring summarizing: A case study. Sino-US English Teaching, 5(8), 29-34.

Mikulecky, Beatrice S. and Jeffries, Linda. (1996). More Reading Power. London: Addison-Wesley Publishing Company.

Moghaddam, S. T. (2007, May). Comparison of native and non-native English speakers in summarizing expository text. Paper presented at the meeting of the Redesigning Pedagogy: Culture, Knowledge and Understanding Conference, Singapore.

Palmer, J. C. (2003). Summarizing techniques in the English language classroom: An International perspective. PASAA, 34, 54-63.

Phelan, Colin and Wren, Julie. (2005). Exploring Reliability in Academic Assessment. Graduate Assistant: UNI office of Academic Assessment.

Scrivener, Jim. (1994). Learning Teaching. Jordan Hill: Oxford Ltd. 
Sotiriou, E. P. (2002). Reading to write: Composition in context. USA: Heinle \& Heinle.

Spratt, M, et al. (2005). The TKT: Teaching Knowledge Test Course. Cambridge : University Press.

Ur, Penny. (1996). A Course in Language Teach ing .New York: Cambridge University Press. 